\title{
The Bacteria and the TirHaloMethanes in Drinking Water Distribution System in Jazan Region
}

\author{
Ahmed Mohamed Reyad ${ }^{1,2 *}$, Mohamed M.A. Shahat ${ }^{1,3}$, Mazahirul Islam Syed ${ }^{1}$ \\ ${ }^{1}$ Biology Department, Faculty of Science, Jazan University, Jazan, Saudi Arabia \\ ${ }^{2}$ Botany Dept. Faculty of Science, Beni-Suef University, Egypt \\ ${ }^{3}$ Department of Zoology, Faculty of Science, AL-Azhar Universit Assiut, Egypt
}

Received: 18 February 2021

Accepted: 13 April 2021

\begin{abstract}
The occurrences of Trihalomethanes (THMs) and heterotrophic bacteria were monitored in water samples from different locations "areas". The water samples we got them water from (El-Shocake RO plant system, Jazan, KSA) over a twelve -month period to investigate the association between (THMs) and heterotrophic bacteria populations. The sampling sites were chosen to cover the entire distribution pipes network of the El-Shocake RO system approximately more than $200 \mathrm{Km}$ distance. A positive association between some bacterial species and THMs concentrations was found at some locations. Bacterial count of some type bacterial species could be used as an indicator for the presence of THMs in distribution systems.

When we considered the relation between THMs and all identified culture-able bacterial isolates we observed that, the increase the concentrations of the THMs in the water increased the percent of gamma- Proteobacteria classes. The highest THMs values were recorded at water samples collected from the south region of Jazan province which included three main cities El-Ahad, El-Dagarer and Samta. We think that, there are many of yet-unknown bacterial strains "aerobic/anaerobic" which have relations with THMs and further studies on the isolation and identification bacteria using other mechanisms.
\end{abstract}

Keywords: Gamma- Proteobacteria, heterotrophic bacteria, Trihalomethanes (THMs), El-Shocake RO plant system, Jazan, KSA

\section{Introduction}

Because of the rapid population growth as well as the increase of drought, getting the fresh water is a worldwide problem. Many coastal areas around the world are famous for by their large cities with high

*e-mail: areyadegy@yahoo.com populations sometime excess 10 million [1]. Seas and oceans represented $96.5 \%$ of the earth's water, thus, seawater desalination is a useful technology for solving water scarcity problems in coastal regions. For decades, many countries in Australia, United States (US) as well as the Middle East and the Mediterranean Basin depend on desalination operations to provided drinking water to their populations [2]. Arabian Gulf region has large number of water desalination plants which have 11 million $\mathrm{m}^{3} /$ day seawater desalination capacities [3]. 
Low costs of energy in the Middle East area as well as development of novel desalination technologies synchronized with highly increasing in freshwater demands in those regions encourage gulf countries to build up reverse osmosis desalination plants like El-Shocake plant [4].

In the recent years, chemicals have been used by diverse routes in our life, due to this continuous use through technology and industry around the world, many health risks appear and should be taken in consideration. Potable water for example, although it is safe or appears safe, may contain a wide variety of chemicals [5]. Tap water contains a lot of chemicals, not all of these chemicals are harmless, because some of them lead to the formation of disinfection by-products. Chemicals, such as disinfectants, in spite of treating and protecting water from pathogen, they also cause other carcinogenic toxic compounds.

Chlorine is the most common disinfectant used for pre-treatment and final disinfection to inactivate bacterial growth and reduce the biofouling formation in the intake structures as well as improve the performance of filters [6]. Chlorination process can be done using three forms which are chemically equivalent forms of chlorine "compressed gas, solid calcium hypochlorite or solutions of sodium hypochlorite" [7]. After water treatment two types of chlorine are present, free available chlorine and combined chlorine. The total chlorine is the sum of both free and combined chlorine. By no means, the disinfectant of free chlorine is more powerful than disinfecting by combined chlorine power [7]. [8] in his project mentioned that, major factors affecting the efficiency of chlorine disinfection power. Beside $\mathrm{pH}$ and temperature other factors have their effect like, chlorine concentration; the nature of the water under treatment as well as its exposure time to chlorine and type of microorganisms need to be killed and its concentration. Chlorine functioning as an antimicrobial agent and because it is non-selective oxidant, it reacts with both organic and inorganic substances in the water as well. The reactions with the inorganic substance may start with few seconds [8]. Ammonia, bromide, iron, manganese and sulphide are the most inorganic substances react with chlorine [9]. On the other hand, reactions with the organic substance may take long time depending on the type of organic particles.

One of the most important consequences of the use of chlorine disinfectant is the production of disinfection by-products (DBPs) that affect public health and lead to an environmental risk. Disinfection by-products (DBPs) like THMs are the results of chlorine reactions with organic particles [10].

In drinking water supplies, scientists discovered more than 600 types of disinfection by products (DBPs) [6]. Trihalomethanes (THMs) represent the most important (DBPs) group because they are abundant, toxic and carcinogenic [11].
From historical point of view, Trihalomethanes (THMs) or Haloform compounds were discovered in 1974 [10]. (THMs) are a group of four organic chemicals that are formed as disinfection by-products (DBPs) when chlorine is used to control microbial contaminants in drinking water reacts with naturally occurring organic matter in water. Balancing and regulations between the disinfection and disinfection by-product (DBPs) is a challenge for the drinking water plant [12]. The four THMs compounds are bromodichloromethane (BDCM), dibromochloromethane (DBCM), tribromomethane (bromoform) and trichloromethane (chloroform). All of these structures resulted from chlorination of water [13]. To avoid more formation of THMs, many water plants use combinations of chlorine and chloramines [14]. Formation of THMs compounds can occur within water treatment plants even during short periods of chlorination [15]. Therefore, attempts for minimizing the formation of DBPs like THMs, during drinking water treatment are potentially valuable. Water companies/plants cannot avoid the usage of chlorines as disinfectants because they are cheap, efficient at eliminating pathogens as well as providing residuals protecting water in distribution networks, thus removing them from the drinking water networks could increase the risk of getting waterborne diseases which constitutes a greater risk than getting cancer by chlorines (DBPs) [11].

In recent years, there have been attempts to find a way for biodegradation of all THM compounds. Seeking powerful microorganisms that can degrade THM directly or via a process called cometabolism of chlorinated solvents may be a promising research. Methanotrophic and nitrifying bacteria were used for biodegradation of THM(s) by cometabolism [16]. Nitrosomonas europaea (ATCC 19718) is an ammoniaoxidizing bacterium showed biodegradation ability of the THMs in different concentrations (50 to $800 \mu \mathrm{g} / \mathrm{L}$ ) [14]. The biodegradation of Halogenated Disinfection Byproducts like THMs in Water Distribution Systems is considered by many workers [17].

Blending desalinated product waters with fresh waters drawn from treated surface water is a preferred operation prior to distribution in Jazan province. When reverse osmosis $\mathrm{RO}$ is mixed with treated surface water, more DBP/THM species will form in the distribution system because hydrophilic organic substances remaining after coagulation, flocculation and sedimentation process and can react with chlorine disinfectant even at low level of dissolved organic carbon (DOC) such as 1-2 $\mathrm{mg} \mathrm{C} / \mathrm{L}$ [18]. According to an international survey studies by [19], more than $60 \%$ of desalination plant operators blending desalinated water with treated surface water during post-treatment processes. In the past few decades, many publications have been conducted to understand the stabilization of desalinated water by adding corrosion inhibitors, adjusting the alkalinity and $\mathrm{pH}$, blending with pre-treated water as well as studying the formation 
and potential toxicity of DBPs/THMs in desalinated and blended waters [4]. About El-Shocake water plant, no research has been conducted to study the effect of THMs formed and/or present in water distribution pipes of Jazan province on the dynamics of bacterial communities.

\section{Materials and Methods}

\section{Sample Collection}

Drinking water samples $(\mathrm{n}=24)$ were collected quarterly starting in Mrach of 2019 until February 2020 from eight different areas (eight cities from north to south are: El-Shocake; El-Darb; Pish; Sabya; Jazan; ElAhad; El-Dagarer and Samtah), all of them follow Jazan province administratively and get their water from ElShocake water plant.

El-Shocake water plant is one of RO plant in KSA that supply fresh water to different areas in Jazan province, in specific point the fresh water stored in dam of the Pish city "90 Km from El-Shocake" mixed with the treated water comes from El-Shocake water plant. In spite of the water good quality from El-Shocake water plant, the water is mainly used only for domestic uses but not for drinking.

Water samples were collected in clean and sterilized $500 \mathrm{~mL}$ glass screw caped bottles. After letting the tap run for a minute or more, water samples were collected directly in to the sterile bottles. The water samples were labeled and transported on ice box to the laboratory for analysis.

Some water quality parameters "Chemical parameters" were recorded as soon as possible. Ammonia, nitrate $\left(\mathrm{NO}_{3}^{-}\right)$, nitrite $\left(\mathrm{NO}_{2}^{-}\right), \mathrm{pH}$, sulfate $\left(\mathrm{SO}_{4}^{--}\right)$and total soluble salts concentrations in all water samples were measured according to [20].

Table 1 provides comprehensive information about water chemical parameters and samples information of each area.

In order to isolate bacteria, $100 \mu \mathrm{mL}$ of the water samples was spread onto MacConkey agar and nutrient agar plates. Water samples were serially diluted and 100 $\mu \mathrm{mL}$ of the 5 fold serial dilutions was spread on to the cultivation agar plates.

The plates were incubated at $37^{\circ} \mathrm{C}$. After incubation, the bacterial colonies were enumerated, characterized, and recorded.

THMs levels in the water samples were taken in consideration when we analyzed bacterial community or in another word, bacterial community analyses were selected based on THMs levels in the water samples.

\section{THM Assay}

In order to detect and measure the THMs in water samples, a total of 24 samples from the eight sites were taken by us and submitted to National Research Centre (NRC), Cairo, Egypt, for measurement. Measuring the concentrations values of bromodichloromethane, bromoform, chlorodibromomethane and chloroform was represented. All these resulting values were collected together on a mass basis to represent total THM in water. THM was determined according to [21]. For THM samples collection during both the field and/or in laboratory work we follow the protocol of [8]. The equipment used by (NRC) for this procedure is gas chromatography-tandem quadrupole mass spectrometry.

\section{Determination of Free/Total Chlorine}

Measuring of free chlorine in water for all collected samples was done by DPD (di-methylphenylene diamine) colorimetric method using Hach pocket colorimeters (Camlab, Cambridge), the determination of total chlorine was the same as the free chlorine with changing the DPD reagent (DPD No. 3) [22].

\section{Measuring of TOC}

All TOC samples were taken through the eight cities and their respective distribution systems. All samples were collected in clean, transparent one-liter plastic bottles. Samples were refrigerated until delivery

Table 1. Comprehensive information about water chemical parameters and samples information of each area.

\begin{tabular}{|c|c|c|c|c|c|c|c|c|}
\hline \multirow{2}{*}{$\begin{array}{c}\text { Chemical parameters } \\
\text { (standard unit) } \mathrm{mg} / 1\end{array}$} & \multicolumn{9}{|c|}{ Area } \\
\cline { 2 - 10 } & Shocake & Darb & Pish & Sabya & Jazan & Ahad & Dagarer & Samata \\
\hline $\mathrm{pH}(6.5-8.5)$ & 7.26 & 7.52 & 7.29 & 7.52 & 7.56 & 7.53 & 7.62 & 7.63 \\
\hline Total soluble salts (1000) $\mathrm{mg} / 1$ & 118 & 124 & 160 & 155 & 170 & 185 & 163 & 190 \\
\hline Ammonia (1.5) & 0.04 & 0.04 & 0.03 & 0.06 & 0.03 & 0.02 & 0.02 & 0.03 \\
\hline $\mathrm{NO}_{2}^{-}(0.3)$ & 0.12 & 0.1 & 0.21 & 0.06 & 0.02 & 0.08 & 0.014 & 0.02 \\
\hline $\mathrm{NO}_{3}^{-}(50)$ & 18.7 & 18.9 & 17 & 7 & 16 & 23 & 31.8 & 36 \\
\hline $\mathrm{SO}_{4}^{--}(250)$ & 22 & 21 & 32 & 24 & 75 & 37 & 52 & 57.5 \\
\hline $\mathrm{CL}^{-}(250)$ & 42 & 42 & 50 & 40 & 73 & 56 & 56 & 60.35 \\
\hline $\mathrm{Fe}(0.3)$ & 0.06 & 0.06 & 0.05 & 0.12 & 0.06 & 0.03 & 0.03 & 0.08 \\
\hline
\end{tabular}


to the NRC laboratories. Samples were prepared according to the manual of analytik jena company using (TOC analytik jena Multi N/C UV HS) instrument.

\section{Bacterial Cultivation, Enumeration and Isolation}

The isolation of bacteria was done by Filtration method according to [23].

The membrane filtration methods can be used with water [24], adequate volumes of the samples, or dilutions, are filtered through cellulose nitrate or acetate membrane filters (47 mm dia., 0.22-0.45 um pore size). The filters are placed onto the surface of plates of bacterial media. The plates are then inverted and incubated for 2-7 days at temperatures ranging from $30-37^{\circ} \mathrm{C}$.

\section{Purification of Colonies}

Bacterial biodiversity was observed and bacterial Colonies were purified by twice sub-culturing using the streaking plate method. Gram staining was carried out using young bacterial cultures. Also, the bacteria colonies were picked up for PCR purpose.

\section{Extraction of Genomic DNA and Identification of PCR Products}

To identify the culture species, DNA from the isolates was extracted using the PureLink Genomic DNA Kit (K182001), bacterial DNA extraction kit was done according to the manufacturer's protocol. Also, the concentration of the extracted DNA was determined spectrophotometrically using (Nano Drop ND 1000, Thermo Scientific, USA). The purified DNA was confirmed by conventional agarose gel $(1 \% \mathrm{w} / \mathrm{v})$.

\section{PCR and Sequencing Work}

Purification as well as standard sequencing for PCR products were carried out by Macrogen Company (Seoul, Korea). Sequencing reactions were done in a MJ Research PTC-225 Peltier Thermal Cycler using a ABI PRISM ${ }^{\circledR}$ BigDyeTM Terminator Cycle Sequencing Kits with AmpliTaq ${ }^{\circledR}$ DNA polymerase (FS enzyme) (Applied Biosystems), following the protocols supplied by the manufacturer. Single-pass sequencing was carried out on each template using the universal primers 27F (5'-AGAGTTTGATC(AC)TGCCTCAG-3') (forward) primer. The fluorescent-labeled fragments were purified from the unincorporated terminators with Big Dye ${ }^{\circledR X}$ Terminator ${ }^{\mathrm{TM}}$ purification protocol. The samples were re-suspended in distilled water and subjected to electrophoresis in an ABI 3730xl sequencer (Applied Biosystems). The sequences were searched for sequence similarity through BLAST(www.ncbi. nlm.nih.gov/BLAST/) [25] and compared to reference sequences of Dengue sero-types detected in BLAST and downloaded from GenBank (www.ncbi.nlm.nih. gov/genbank/).

\section{Results and Discussion}

\section{Water Chemical Parameters}

According to Table 1, the $\mathrm{pH}$ in all samples did not exceed 7.63 and ranged between 7.26 and 7.63, and did not revealed a strong gradient with sample distance from El-Shocake to Samta city. This indicates that all microorganisms are in neutral range.

It was mentioned that the higher $\mathrm{pH}$ facilitated THMs formation, and the positive relationship between higher $\mathrm{pH}$ and the increase in both rate and quantity of THMs formed was recorded by many workers [26].

Total soluble salts tend to increase from El-Shocake to Samatah, the deviation in Sabya and El-Dagarer values may refer to the type of storage tank used over house building. Even if the inorganic particles found in drinking waters are natural or from anthropogenic sources, they have particular significance concerning the formation of disinfection by-products [8]. The anion bromide $(\mathrm{Br})$ from geologic erosion and salt water intrusion plays a significant and concerning role in THMs formation [27, 28].

Ammonium concentrations ranged between $0.02 \mathrm{mg} / \mathrm{L}^{-1}$ in El Ahad and Dagarer to $0.06 \mathrm{mg} / \mathrm{L}^{-1}$ in Sabya. Ammonium values in water samples were considerably low and below the maximum allowed level $\left(0.5 \mathrm{mg} / \mathrm{L}^{-1}\right)$. It is possible that nitrogen availability might not be high enough to support transforming populations in water [29].

The lower nitrate concentration was $7 \mathrm{mg} / \mathrm{L}^{-1}$ in Sabya and the maximum was $36 \mathrm{mg} / \mathrm{L}^{-1}$ in Samta. While, the lower nitrite concentration was $0.014 \mathrm{mg} / \mathrm{L}^{-1}$ in El-Dagarer and the maximum was $0.21 \mathrm{mg} / \mathrm{L}^{-1}$ in Pish. The lower Sulphate concentration was $22 \mathrm{mg} / \mathrm{L}^{-1}$ in El-Shoquic and the maximum was $75 \mathrm{mg} / \mathrm{L}^{-1}$ in Jazan. The lower Ferric ions concentration was $0.03 \mathrm{mg} / \mathrm{L}^{-1}$ in El Ahad and the maximum was 0.12 in Sabya. The biodegradations and transformations of disinfecting byproducts like DCM are affected by electron acceptors [30]. The predominant electron acceptors like sulfate, nitrate or ferric iron play significant role in anaerobic biodegradation of disinfecting by-products [31]. In case of facultative anaerobic biodegradation of disinfecting by-products, bacteria could use both predominant electron acceptors and/or oxygen as terminal electron acceptors [31, 32].

\section{Free $\mathrm{Cl}$, Total Organic Carbon and Trihalomethane}

Along the studied area, data in Table 2 showed that, the mean average values for Free Chlorine, Total Organic Carbon concentrations as well as Trihalomethane formation showed significant changes 
Table 2. Free $\mathrm{Cl}$, Total Organic Carbon and Trihalomethane.

\begin{tabular}{|c|c|c|c|}
\hline Area & $\begin{array}{c}(\mathrm{TOC}) \\
\mathrm{mg} / \mathrm{l}\end{array}$ & $\begin{array}{c}\mathrm{CL} \\
(\mathrm{mg} / \mathrm{l})\end{array}$ & $\begin{array}{c}\text { TTHM tap water } \\
(\mu \mathrm{g} / \mathrm{l})\end{array}$ \\
\hline Shoc & $1.10 \pm 0.31$ & $0.18 \pm 0.13$ & $9.87 \pm 2.89$ \\
\hline Darb & $1.4 \pm 0.31$ & $0.18 \pm 0.13$ & $12.54 \pm 2.58$ \\
\hline Pish & $2.74 \pm 0.18$ & $0.20 \pm 0.22$ & $24.17 \pm 1.16$ \\
\hline Sabya & $4.63 \pm 0.11$ & $0.26 \pm 0.21$ & $40.98 \pm 0.90$ \\
\hline Jazan & $4.71 \pm 0.19$ & $0.19 \pm 0.15$ & $41.48 \pm 1.90$ \\
\hline Ahad & $5.54 \pm 0.28$ & $0.29 \pm 0.13$ & $48.60 \pm 2.74$ \\
\hline Dagar & $6.00 \pm 0.11$ & $0.22 \pm 0.21$ & $54.12 \pm 3.67$ \\
\hline Samtah & $6.84 \pm 0.16$ & $0.27 \pm 0.20$ & $61.43 \pm 2.71$ \\
\hline
\end{tabular}

in their values. For all three parameters the lower mean values were recorded in El-Shocake while, the higher mean values were recorded in Samata. From the general view, all values tended to increase from water source "El-Shocake water plant" to Samta city because the water travel for long distances, high temperature degrees in Jazan province during the year and the mixing of fresh water of Pish Dam with water from ElShocake water plant as well as the type of pipes used in water transfer.

Tap water temperature measured revealed that, $44^{\circ} \mathrm{C}$ was the maximum temperature recorded in summer while $32^{\circ} \mathrm{C}$ was the minimum temperature in winter recorded in Jazan. This referred to the hot nature of Jazan weather along the year and tap water stored and supplied from a reservoir tank mainly lay on the top of the building direct to the sun light. [8] mentioned that, the total organic carbon (TOC) is the most widely used parameter for measuring the organic content in water and a number of researchers proposed models to find a linear relationship between the parameter and the bulk chlorine decay constant (KB) [33-35].

Many related water research projects revealed that, the increase in the organic carbon in the water increases both the rate and THMs formation $[9,36,37]$.

The formation of THM inside the water pipes stared from El-Shocake plant and increased with the water move for a long distance. The results revealed that, formation of THM increased when rain fresh water mixed with RO treated water. The lower mean values were recorded in El-Shocake $(9.87 \mu \mathrm{g} / \mathrm{l})$ while, the higher mean values were recorded in Samata $(61.43 \mu \mathrm{g} / \mathrm{l})$. The reactions between chlorine and naturally occurring organic compounds leads to THMs formation via the "classical" haloform reaction mechanism, thus it is accepted that the THM formation increases with increasing both chlorine dose and TOC. THMs as a member of DBPs that have been quantified in drinking water are generally present at sub- $\mu \mathrm{g} / \mathrm{l}(\mathrm{ppb})$ levels, and their concentrations will vary according to both water source and the treatment of the water [8]. According to many sources THMs, represent the largest fraction of disinfection by-products "DBP" to be found in treated water and close to $50 \%$ of all halogenated DBP in drinking water [38, 39]. In 2007 the European Union Communities for drinking water (Regulations (No. 2), 2007) determined the THMs value in the limit of $100 \mu \mathrm{g} / 1$ [9].

Depending on The European Standard for water analysis guidelines, the total organic carbon (TOC) represent the carbon content of dissolved and undissolved organic matter present in the water. Because TOC is heterogeneous substance, it does not give any information about the nature of the organic substance.

Also, according to UK Water Industry Research, THM levels may exceed $100 \mu \mathrm{g} / \mathrm{l}$ if the TOC more than $4.0 \mathrm{mg} / 1$ while the residence time in the network is 2-3 days and if the free residual chlorine is to be maintained at the tap [9]. Therefore, remedial works will be necessary if the levels of TOC are more than $4.0 \mathrm{mg} / \mathrm{l}[40]$.

The United States Environmental Protection Agency (EPA) in its last edition of the Drinking Water Standards and Health Advisories Tables (DWSHA) as well as its Drinking Water Guidance on Disinfection By-Products, recommended that, the limit for the THMs value should not exceed $80 \mu \mathrm{g} / 1$ [40]. According to the (EPA) the THMs in Jazan water is within the safe limit.

\section{Water Bacteria Counts}

Bacterial count is one of the most important parameters used to assess drinking water quality. Bacterial enumeration revealed a characteristic parameter for the drinking water and assay reflects microbial environmental survival and resistance to treatment. A number of documents contain detailed information on bacterial count as an essential parameter $[41,42]$.

Data in Table 3 revealed that, the mean average values for bacterial counts showed significant changes. Depending upon the areas and their distance from the RO plant "with the exception of data we got from Dagarer area" there is a linear relationship between both bacterial count with the distance from RO plant. In other word, the more the distance we travel from the RO plant the more the increase in bacterial number.

According to bacterial media used, the blood agar and the nutrient agar media showed the highest bacterial numbers in contrast to MacConkey agar medium composition of each medium. The blood agar and nutrient agar media mainly contain many gradients that enhance and support the bacterial growth of both Gram positive and Gram negative bacterial type, while MacConkey agar medium support the growth of some Gram negative bacteria.

Family Enterobacteriaceae "enteric bacteria" and the genus Pseudomonas are non-fastidious gram-negative bacteria can be grown on selective and differential media like MacConkey agar (MAC) [43]. 
Table 3. Bacteria number with different media.

\begin{tabular}{|c|c|c|c|}
\hline \multirow{2}{*}{ Area } & Blood Agar & Mac Conkey agar & Nutrient agar \\
\cline { 2 - 4 } & (mean) & (mean) & (mean) \\
\hline Shoc & $5.00 \pm 0.82$ & $0.00 \pm 0.00$ & $4 \pm 0.00$ \\
\hline Darb & $17.00 \pm 2.95$ & $0.00 \pm 0.00$ & $14 \pm 2.65$ \\
\hline Pish & $41.00 \pm 7.12$ & $0.00 \pm 0.00$ & $35 \pm 6.25$ \\
\hline Sabya & $47.00 \pm 3.75$ & $12.00 \pm 1.73$ & $49 \pm 4.58$ \\
\hline Jazan & $47.00 \pm 4.97$ & $16.00 \pm 1.41$ & $49 \pm 2.00$ \\
\hline Ahad & $88.00 \pm 8.54$ & $15.00 \pm 0.00$ & $72 \pm 5.29$ \\
\hline Dagar & $104.00 \pm 11.27$ & $40.00 \pm 3.61$ & $98 \pm 8.66$ \\
\hline Samtah & $102.00 \pm 27.19$ & $20.00 \pm 1.74$ & $83 \pm 2.65$ \\
\hline
\end{tabular}

In the traditional laboratory work for water quality assurance, the use of MacConkey agar is not enough and it is presumptive medium for bacterial identification process, thus other differential media should be used. Also, it is important to carry out some biochemical tests as confirmation experimental tests for final identification [44].

From Table 3, Samples from areas (El-Shocake, El-Darb and Pish) did not show any bacterial growth on MacConkey agar. The appearance of bacterial colonies on MacConkey agar started with exponential relationship at areas of (Sabya, Jazan, El-Ahad and ElDagarer).

In general, the more the distance from El-Shocake RO plant the more the appearance of bacterial colonies on all media used.

It is well known that, the standard total bacterial count should not exceed $50 \mathrm{~cm}$ at $37^{\circ} \mathrm{C}$ within $24 \mathrm{~h}$ or not exceed $50 \mathrm{~cm}$ at $22^{\circ} \mathrm{C}$ within $48 \mathrm{~h}$. Also, E. coli; Faecal bacteria and Faecal Streptococci should not appear in water drinking samples. The dramatic increase in total bacterial count in water samples after jazan area may referred to the appearance of some bacterial species with high resistance to chlorine or old water pipes as well as the type of pipes used. The correlation between the increasing of bacterial number in cities far away from the RO plant may be due to treatment problems, risks pointing to recontamination in distribution or lack of residual chlorine [41].

The bacterial cells can be recovered using a membrane filter or directly cultured on differential and selective solid media in order to detect and assay via the developing bacterial colonies. Then the bacterial colonies are further characterized to confirm their identity. Mainly, the cultured bacteria must be confirmed by one or more of several methods, using other differential and selective media; biochemical, metabolic and other phenotypic analyses; immunological analyses and nucleic acid analysis like 16sDNA sequencing [45, $46,47]$.
Although, many bacterial organisms can be cultured form long time ago, culturing them from water still underdeveloped from technologically point of view [48].

\section{Distribution of Major Taxonomic Bacterial Groups}

It was observed that, the structure of the microbial community changed under the influence of distance and THMs. Table 4 showed that, all the culture-able bacterial isolated strains lay under two main bacterial phyla Firmicutes $(\approx 46.3 \%$ ) and Proteobacteria $(\approx 53.7 \%)$. Also, the phylum Firmicutes was the dominant and the only phylum in water samples collected from the north areas. While, the phylum Proteobacteria was the dominant phylum in water samples collected from the south areas. Phylum Proteobacteria was detected as a dominant group of bacteria in the fresh water by many workers $[29,49]$.

The phylum Firmicutes was represented by only one class which is class bacilli. Class bacilli was represented by two orders Bacillales $(\approx 44.5 \%)$ and Lactobacillales $(\approx 1.8 \%)$. On the other hand, the phylum Proteobacteria was represented by three classes alpha-Proteobacteria $(\approx 10.3 \%)$, beta-Proteobacteria $(\approx 16.7 \%)$ and gammaProteobacteria ( $\approx 26.7 \%)$.

Phylum Firmicutes with its order Bacillales was the most dominant bacterial group and was represented in all water samples. The Firmicutes may play an important role in reductive dechlorination of THMs as well as other related by-products.

Although alpha-Proteobacteria was the only class of phylum Proteobacteria appeared in water samples from the north areas, alpha-Proteobacteria showed the lower percent bacterial isolates comparing with beta and gamma Proteobacteria classes. In general phylum Proteobacteria members increased with increasing in distance from RO water plant and increasing in THMs concentration in water.

Guo and his coworkers found that, Betaproteobacteria and Alphaproteobacteria were the most abundant bacterial groups when studied the bacterial community compositions of two neighboring freshwater lakes in China, their studied revealed that, Betaproteobacteria was represented by (24.1\%) and Alphaproteobacteria was (11.3\%) [50]. In contrast, Alphaproteobacteria was recorded as a dominant class of Proteobacteria in some water research projects [51, 52].

Despite of the differences in temperature degrees throughout the study areas north and south were not high, we cannot exclude the effect of temperature on bacterial distribution and diversity, specially some bacteria are sensitive to temperature changes. The temperature may effect directly on the bacterial growth and their presence in drinking water system [29] or indirectly via affecting and changing the disinfectant levels in the water disruption system [53].

The class beta-Proteobacteria occupied a significant percent and made up a noticeable fraction of the bacterial 
Table 4. Distribution of major taxonomic bacterial groups in relation with different cities of jazan province.

\begin{tabular}{|c|c|c|c|c|c|c|}
\hline Area & Phylum & Class & Order - (ales) & $\begin{array}{c}\text { Family - } \\
\text { (aceae) }\end{array}$ & Gram Reaction & $\mathrm{n} / \mathrm{Tn}$ \\
\hline Shoc & Firmicutes & Bacilli & Bacill- & Bacill- & $\mathrm{ve}+($ Bacillus sp. AER315-1) & $5 /(5)$ \\
\hline \multirow{2}{*}{ Darb } & Firmicutes & Bacilli & Bacill- & Bacill- & ve+ (Bacillus sp. BS3(2011) & $6 /(17)$ \\
\hline & Firmicutes & Bacilli & Lactobacill- & Aerococc- & $\mathrm{ve}+$ Aerococcus viridans & $8 /(17)$ \\
\hline \multirow{2}{*}{ Pish } & Firmicutes & Bacilli & Bacill- & Bacill- & $\mathrm{ve}+($ Bacillus sp. BS3(2011) & $24 /(33)$ \\
\hline & Firmicutes & Bacilli & Bacill- & Bacill- & ve+ Bacillus sp. strain HK17 & $9 /(33)$ \\
\hline \multirow{3}{*}{ Sab } & Firmicutes & Bacilli & Bacill- & Bacill- & $\mathrm{ve}+($ Bacillus sp. BS3(2011) & $24 /(47)$ \\
\hline & Firmicutes & Bacilli & Bacill- & Bacill- & ve+ Bacillus sp. strain HK17 & $19 /(47)$ \\
\hline & Proteobacteria & A-Proteobacteria & Rhodobacter- & Rhodobacter- & ve- Pannonibacter & $4 /(47)$ \\
\hline \multirow{3}{*}{$\mathrm{Jaz}$} & Firmicutes & Bacilli & Bacill- & Bacill- & ve+ Bacillus sp. strain HK17 & $16 /(47)$ \\
\hline & Firmicutes & Bacilli & Bacill- & Bacill- & $\mathrm{V}+$ cocii (Jeotgalicoccus nanhaiensis) & $8 /(47)$ \\
\hline & Firmicutes & Bacilli & Bacill- & Bacill- & $\mathrm{ve}+($ Bacillus sp. BS3(2011) & $20 /(47)$ \\
\hline \multirow{6}{*}{ Ahad } & Firmicutes & Bacilli & Bacill - & Bacill- & $\mathrm{ve}+($ Bacillus sp. BS3(2011) & $19 /(88)$ \\
\hline & Firmicutes & Bacilli & Bacill- & Bacill- & $\mathrm{V}+\operatorname{cocii}(J$. nanhaiensis $)$ & $10 /(88)$ \\
\hline & Proteobacteria & A- Proteobacteria & Unclassified & Unclassified & Ve- Uncultured bacterium & $11 /(88)$ \\
\hline & Proteobacteria & B-Proteobacteria & Burkholderi- & Alcaligen- & ve- (Alcaligenes faecalis strain) & $19 /(88)$ \\
\hline & Proteobacteria & G- Proteobacteria & Xanthomonad- & Xanthomonad- & ve- Pseudoxanthomonas sp. B14 & $7 /(88)$ \\
\hline & Proteobacteria & G- Proteobacteria & Enterobacter- & Morganell- & Proteus mirabilis & $22 /(88)$ \\
\hline \multirow{7}{*}{ Dagar } & Firmicutes & Bacilli & Bacill- & Bacill- & $\mathrm{V}+\operatorname{cocci}(J$. nanhaiensis $)$ & $7 /(104)$ \\
\hline & Firmicutes & Bacilli & Bacill - & Bacill- & $\mathrm{ve}+($ Bacillus sp. BS3(2011) & $18 /(104)$ \\
\hline & Proteobacteria & A- Proteobacteria & Unclassified & Unclassified & ve- Uncultured bacterium & $13 /(104)$ \\
\hline & Proteobacteria & B-Proteobacteria & Burkholderi- & Alcaligen- & ve- (Alcaligenes faecalis strain) & $11 /(104)$ \\
\hline & Proteobacteria & G- Proteobacteria & Enterobacter- & Morganell- & Proteus sp. & $26 /(104)$ \\
\hline & Proteobacteria & G- Proteobacteria & Enterobacter- & Morganell- & Proteus mirabilis & $23 /(104)$ \\
\hline & Proteobacteria & G- Proteobacteria & Xanthomonad- & Xanthomonad- & Stenotrophomonas & $11 /(104)$ \\
\hline \multirow{5}{*}{ Samt } & Firmicutes & Bacilli & Bacill - & Bacill- & ve+ (Bacillus sp. BS3 (2011) & $9 /(102)$ \\
\hline & Proteobacteria & A- Proteobacteria & Unclassified & Unclassified & ve- Uncultured bacterium & $18 /(102)$ \\
\hline & Proteobacteria & B-Proteobacteria & Burkholderi- & Alcaligen- & ve- (Alcaligenes faecalis strain) & $23 /(102)$ \\
\hline & Proteobacteria & B-Proteobacteria & Burkholderi- & Alcaligen- & Ve- Paenalcaligenes suwonensis & $22 /(102)$ \\
\hline & Proteobacteria & G- Proteobacteria & Enterobacter- & Morganell- & Proteus sp. & $31 /(102)$ \\
\hline
\end{tabular}

n/Tn (bacterial number/ total bacterial number) El-Shocake; El-Darb; Pish; Sabya; Jazan; El-Ahad; El-Dagarer and Samtah

isolates from south areas $(\approx 16.7 \%)$ of the total identified isolates and $25.5 \%$ if we consider the south areas only "El-Ahad, El-Dagarer and Samta". All bacteria in the class beta-Proteobacteria were in the order Burkholderiales, this order mostly included bacteria with aerobic metabolism such as genus Alcaligenes. Bacterial group in this order may encourage the ability for aerobic biodegradation of THMs and/or related chlorine by-products. similar results were detected by [29]. Polaromonas sp. an aerobic bacterial species belonging to order Burkholderiales capable of growth on chlorine compound like cis-dichloroethene as a sole carbon and energy source was isolated by $[54,55]$.

Gamma -Proteobacteria the most important class of bacteria in the bacterial isolates from south area was $(\approx 26.7 \%)$ of the total bacterial isolates and $40.8 \%$ if we consider the south areas only "El-Ahad, El-Dagarer and Samta". (Table 4). Gamma -Proteobacteria as the dominant group in isolates of the south area contains two orders Enterobacterales and Xanthomonadales both are Gram-negative, aerobic, rod-shaped bacterium especially Xanthomonadales is strictly aerobic [56]. 
The class alpha-Proteobacteria was represented by two orders, one is Rhodobacterales $(\approx 0.89 \%)$ and three unclassified order $(\approx 9.4 \%)$. While, the class betaProteobacteria was represented by only one order which is Burkholderiales $(\approx 16.7 \%)$. The third class gammaProteobacteria was represented by two orders, order Xanthomonadales $(\approx 4 \%$ ) and the order Enterobacteriales $(\approx 22.7 \%)$.

On the family level, the most predominant family Bacillaceae $(\approx 44.5 \%)$ followed by families Morganellaceae and Alcaligenaceae represented by $(\approx 22.7 \%$ and $\approx 16.7 \%)$ respectively. The unclassified family and the Xanthomonadaceae family were represented by $(\approx 9.4 \%$ and $\approx 4 \%)$ respectively. the remaining families Aerococcaceae and Rhodobacteraceae were represented by only $(\approx 1.8 \%$ and $\approx 0.9)$ respectively. The families Bacillaceae and Morganellaceae showed the highest percent in total bacterial count followed by families Alcaligenaceae and Xanthomonadaceae.

All the identified bacterial isolates were under nine Genera and the tenth is unclassified genus. The most predominate genera were Bacillus $(\approx 38.9 \%)$; Proteus $(\approx 22.7 \%)$; Alcaligenes $(\approx 11.8 \%)$; Jeotgalicoccus $(\approx 5.5 \%)$ and Paenalcaligenes $(\approx 4.9 \%)$ respectively. While, the known remaining genera were Stenotrophomonas $(\approx 2.5 \%)$; Aerococcus $\quad(\approx 1.8 \%)$; Pseudoxanthomonas $(\approx 1.6 \%)$ and Pannonibacter $(\approx 0.9 \%)$. The tenth unclassified Genus was represented by $(\approx 9.4 \%)$.

Many genera related to gamma -Proteobacteria showed the ability to oxidize aromatic hydrocarbons [57, 58], couple oxidation of organic substrates with metal reduction as well as reduction of tetrachloroethene and triclorethene to dicloroethene [29, 59]. Therefore, the presence of gamma-Proteobacteria as dominant genera in south areas may suggest suitable conditions for reductive dechlorination reactions.

The genus Pseudoxanthomonas was represented by $(\approx 7.9 \%)$ and $(\approx 10.5 \%)$ in two cities only "El-Ahad and El-Dagarer" respectively. The genus may play a role in THMs degradation. Only a few bacterial strains were reported for their ability to degrade all BTEX compounds, a bacterial strain belonging to genus Pseudoxanthomonas, the strain was able to degrade (BTEX) compounds, and it was the first time for the genus Pseudoxanthomonas to be recorded as a (BTEX) degrader [60, 61].

When we considered the relation between THMs and all identified culture-able bacterial isolates we observed that, the increase in the concentrations of the THMs in the water the increase the percent of gammaProteobacteria classes. The highest THMs values were recorded at water samples collected from the south region of Jazan province which included three main cities El-Ahad, El-Dagarer and Samta.

More specifically, Bacterial isolates classified as Proteus sp., Pseudoxanthomonas sp., Bacillus sp. and Jeotgalicoccus sp. were the most dominant bacterial isolates. This might be due to a specific mechanism(s) present in these bacterial isolates which enable them to tolerate/degrade THMs compounds.

A superfamily of enzymes contains glutathione transferases enzymes "GST" that play a key role in cellular detoxification and widely distributed in bacteria. Bacterial GST enzymes are involved in different important processes like reductive dechlorination, antimicrobial drug resistance, biodegradation of xenobiotics compounds, biotransformation of dichloromethane, degradation of lignin and atrazine and protection against chemical and oxidative stresses beside detoxification process [61, 62].

[63] detected more than 10 GST genes in Pseudomonads species. While three different forms of GSTs were identified in Proteus mirabilis [64].

Proteus mirabilis is a facultative anaerobic, Gram-negative, rod-shaped, motile bacterium and widely distributed in soil and water [65]. Genera like Proteus and Providencia, are so close in the taxonomic position and both are lying under class Proteobacteria.

The transferase enzymes have important role in antibiotic resistance of Providencia stuartii [66]. [63] suggested that, when there are changes in growth conditions, GSTs play regulatory roles in the adaptation of Proteobacteria. This might explain the increase of Proteobacteria members in water samples from south areas with increase THMs concentration.

Chlorinated methanes could be undergoing aerobic bio-degradable processes and compounds like chloroform and dichloromethane may be degraded under aerobic conditions [61]. An aerobic biodegradation of Chloroform was recorded [67, 68]. Aerobic biodegradation of dichloromethane via dechlorination process and transformed to formaldehyde was studied [69]. Microorganisms such as Pseudomonas mendocina KR1 could degrade Chloroform and could use toluene as carbon and energy sources. A wide variety of methylotrophic bacteria such as Bacillus sp., have been shown to degrade dichloromethane with growth [61, 67, 69]. Bacterial species like Rhodococcus sp. considered as a degrader for multiple volatile organic compounds, these bacterial type could degrade hexane, dichloromethane and other recalcitrant hydrocarbons $[70,71]$. Biodegradation of dichloromethane is associated with dichloromethane dehalogenase enzyme which is a type of GST enzymes [61]. The identification revealed that, some identified bacterial isolates with no publications associated with biodegradation of the THM(s), but they might play a role or implicated by any way in the biodegradation process. For example, it was considered that Methylobacterium extorquens DM4 acquired the dcmA gene through horizontal gene transfer $[72,73]$. The acquired dcmA gene participated in metabolic pathways, such as stress responses, regulations, cell structure adjustments and chloride export [74, 75]. Microbes have the ability to degrade DCM as non-growth substrates have also been isolated. Methylosinus trichosporium OB3b that degrade DCM 
used a methane monooxygenase was recorded as promising bacteria for environmental remediation [76, 77]. While, Nitrosomonas europaea could degrade DCM and oxidize methane using ammonia monooxygenase enzymes [14].

[78] purified a DCM dehalogenase enzyme from a dichloromethane (DCM)-degrading bacterial strain called WZ-12, the strain was classified as Bacillus circulans. Compering 16sDNA "length $\geq 1400 \mathrm{bp}$ " of the different Bacillus strains we isolated with that of Bacillus circulans strain, there were similarity between 92.85-93.82\%.

There was an inverse relationship between Firmicutes and Proteobacteria, the enrichment the Firmicutes group the depleted the Proteobacteria group and vice versa. Depending on the factor of time and distance and other environmental factors, THMs as well as any chlorine by-products have been recorded in the water as complex mixtures of varying chlorine content, there is not a single process that, by itself, could totally remove THMs from the environment. This may be due to some chemical and environmental conditions but finally all these bacterial genera may accomplish the ultimate goal of complete degradation of THMs and/or other related chlorine by-products in the environment $[79,80]$.

Depending upon the classical cultivation bacterial media, only two bacterial phyla were revealed, maybe if we use another selective media we will get additional types of bacteria. Also, we think that, we need another approach like advanced molecular tools that may give estimation for the real microbial populations in the water.

\section{Conclusion}

We need another discovery journey to detect the reasons of bacterial increasing number. From microbiological point of view and according to the preliminary data in Table 3 and identified bacterial samples in Table 4 water samples from areas of El-Shocake; El-Darb; Pish; Sabya and Jazan are totally safe and can be used for drinking. Bacteria or some bacterial species as well as THMs can change after treatment and through the distribution system [59].

There is a significant need to change some daily human activities and change old pipes that increase the potential for microbial or chemical contamination of drinking-water while traveling from the sources to the Consumers' taps.

However, water quality can vary rapidly, and all systems are at risk of occasional failure. For example, rainfall can greatly increase the levels of microbial contamination in source waters, and waterborne outbreaks often occur following rainfall. Results of analytical testing must be interpreted taking this into account.

\section{Acknowledgment}

The first author is highly grateful to the Deanship of Scientific Research, Jazan University, for awarding the project grant Ref. No. JUP8//000379, for financial assistance and carrying out this investigation. As a team we are highly indebted to the contribution from every one for this article.

\section{Conflict of Interest}

The authors declare no conflict of interest.

\section{References}

1. TIBBETTS J. Coastal cities: living on the edge. Environmental Health Perspectives, 110 (11), A674, 2002.

2. DAVENPORT D.M., DESHMUKH A., WERBER J.R., ELIMELECH M. High-Pressure Reverse Osmosis for Energy-Efficient Hypersaline Brine Desalination: Current Status, Design Considerations, and Research Needs. Environmental Science \& Technology Letters, 5, 467, 2018.

3. SHAFFER D.L., ARIAS CHAVEZ L.H., BEN-SASSON M., ROMEROVARGAS CASTRILLON S., YIP N.Y., ELIMELECH M. Desalination and Reuse of High-Salinity Shale Gas Produced Water: Drivers, Technologies, and Future Directions. Environmental Science and Technology, 47, 9569, 2013.

4. KIM D., AMY G.L., KARANFIL T. Disinfection byproduct formation during seawater desalination: A Review. Water Research, 81, 343, 2015.

5. RICHARDSON S.D., TERNES T.A. Water Analysis: Emerging Contaminants and Current Issues. Analytical Chemistry, 83 (12), 4614, 2011.

6. GINGERICH D.B., GROL E., MAUTER M.S. Fundamental challenges and engineering opportunities in flue gas desulfurization wastewater treatment at coal fired power plants. Environmental Science: Water Research \& Technology, 4, 909, 2018.

7. VIDIC R.D., BRANTLEY S.L., VANDENBOSSCHE J.M., YOXTHEIMER D., ABAD J.D. Impact of Shale Gas Development on Regional Water Quality. Science, 340 (6134), 1, 2013.

8. BROWN D. The management of Trihalomethans in water supply systems. A thesis submitted to the University of Birmingham for the degree of Doctor of Philosophy, Civil Engineering College of Engineering and Physical Science the University of Birmingham, 2009.

9. RAMAVANDI B., FARJADFARD S., ARDJMAND M., DOBARADARAN S. Effect of water quality and operational parameters on trihalomethanes formation potential in Dez River water, Iran. Water Resources and Industry, 11, 1, 2015.

10. ROOK J.J. Haloforms in Drinking Water. Journal American Water Works Association, 68, 168, 1976.

11. VALDIVIA-GARCIA M. Trihalomethanes from precursors to management strategies. A Thesis submitted to Newcastle University in partial fulfillment of the requirements for the degree of Doctor of Engineering in the Faculty of Science, Agriculture and Engineering School of Civil Engineering and Geosciences Cassie Building, 2017. 
12. USEPA. National primary drinking water regulations: Stage 2 disinfectants and disinfection byproducts rule. Federal Register, 71, 388, 2006.

13. CASARETT AND DOULL'S. Toxicology. The Basic Science of Poisons, $6^{\text {th }}$ Edition. Klaassen, C.D., ed. McGraw-Hill Publishing Co., Inc., New York, 2001.

14. WAHMAN D.G., MAESTRE J.P., SPEITEL JR G.E. Monochloramine Cometabolism by Nitrifying Biofilm Relevant to Drinking Water. American Water Works Association, 108 (7), 362, 2016.

15. WANGA F., RUAN M., LINA H., ZHANG Y., HONG H., ZHOU X. Effects of ozone pretreatment on the formation of disinfection by-products and its associated bromine substitution factors upon chlorination/chloramination of Tai Lake water. Science of The Total Environment, 475 (15), 23, 2014.

16. FRASCARI D., ZANAROLI G., DANKO A.S. In situ aerobic cometabolism of chlorinated solvents: A review. Journal of Hazardous Materials, 283, 382, 2014.

17. YANG C, QIAN H, LI X, CHENG Y., HE H., ZENG G., XI J. Simultaneous removal of multicomponent VOCs in biofilters. Trends in Biotechnology, 36 (7), 673, 2018.

18. ZHAO Y., XIAO F., WANG D., YAN M., BI Z. Disinfection byproduct precursor removal by enhanced coagulation and their distribution in chemical fractions. Journal of Environmental Sciences, 25 (11), 2207, 2013.

19. DURANCEAU S.J., PFEIFFER-WILDER R.J., DOUGLAS S.A., PENA-HOLT N., WATSON I. Posttreatment Stabilization of Desalinated Permeate. Water Research Foundation, Denver, CO. Technical Report for, 2011.

20. KHATER A.E.M., AL-JALOUD A., EL-TAHER A. Quality Level of Bottled Drinking Water Consumed in Saudi Arabia. Journal of Environmental Science and Technology, 7 (2), 90, 2014.

21. WHO. Trihalomethanes in Drinking Water: Background Document for Development of WHO Guidelines for Drinking Water Quality. World Health Organisation, 2005.

22. 22. PALIN, A.T. The Determination of Free and Combined Chlorine in Water by the Use of Diethyl-p-phenylene Diamine. Journal American Water Works Association, 49 (7), 873, 1957.

23. BROCK T.D. Membrane Filtration: A User's Guide and Reference Manual. science and technology, Madison Wisconsin, 1983.

24. MANAIA C.M., DA COSTA M.S. Characterization of halotolerant Thermus isolates from shallow marine hot springs on S. Miguel, Azores. Journal of General Microbiology, 137, 2643, 1991.

25. ALTSCHUL S.F., MADDEN T.L., SCHÄFFER A.A., ZHANG J., ZHANG Z., MILLER W., LIPMAN D.J. Gapped BLAST and PSI-BLAST: a new generation of protein database search programs. Nucleic Acids Research, 25 (17), 3389, 1997.

26. BENSON N.U., AKINTOKUN O.A., ADEDAPO A.E. Disinfection Byproducts in Drinking Water and Evaluation of Potential Health Risks of Long-Term Exposure in Nigeria. Journal of Environmental and Public Health, 2017, 1, 2017.

27. HEEB M.B., CRIQUET J., ZIMMERMANN-STEFFENS S.G., VON GUNTEN U. Oxidative treatment of bromidecontaining waters: Formation of bromine and its reactions with inorganic and organic compounds - A critical review. Water Research, 48, 15, 2014.

28. MERYEM S. Removal of Bromide from Natural Waters: Bromide-Selective vs. Conventional Ion Exchange Resins.
A Thesis Presented to the Graduate School of Clemson University in Partial Fulfillment of the Requirements for the Degree Master of Science Environmental Engineering \& Science, 2019. (https://tigerprints.clemson.edu/all theses/3217).

29. NUNEZ A.E. Microbial community structure dynamics in Ohio river sediments during reductive dechlorination of PCBS. A dissertation submitted in partial fulfillment of the requirements for the degree of Doctor of Philosophy in the College of Agriculture at the University of Kentucky, 2008.

30. WRIGHT J., KIRCHNER1 V., BERNARD W., ULRICH N., MCLIMANS C., CAMPA M.F., HAZEN T., MACBETH T., MARABELLOD., MCDERMOTT J., MACKELPRANG R., ROTH K., LAMENDELLA R. Bacterial Community Dynamics in DichloromethaneContaminated Groundwater Undergoing Natural Attenuation. Frontiers in Microbiology, 8, 1, 2017.

31. KLEINDIENST S., CHOUREY K., CHEN G., MURDOCH R.W., HIGGINS S.A., IYER R., CAMPAGNA S.R., MACK E., SEGER E.S., HETTICH R.L., LÖFFLER F.E. Proteogenomics Reveals Novel Reductive Dehalogenases and Methyltransferases Expressed during Anaerobic Dichloromethane Metabolism. Applied and Environmental Microbiology, 85 (6), 1, 2019.

32. GHATTAS A., FISCHER F., WICK A., TERNES T.A. Anaerobic biodegradation of (emerging) organic contaminants in the aquatic environment. Water Research, 116, 268, 2017

33. NEJJARI F., PUIG V., PÉREZ R., QUEVEDO J., CUGUERÓ M.A., SANZ G., MIRATS J.M. Chlorine Decay Model Calibration and Comparison: Application to a Real Water Network. Procedia Engineering, 70, 1221, 2014.

34. SONIA A.H., ISTVAN L. Influence of water quality characters on kinetics of chlorine bulk decay in water distribution systems. International Journal of Applied Science and Technology, 5 (4), 64, 2015.

35. AL HEBOOS S., LICSKÓ I. Application and Comparison of Two Chlorine Decay Models for Predicting Bulk Chlorine Residuals. Periodica Polytechnica Civil Engineering, 61 (1), 7, 2017.

36. SYED J.H., MALIK R.N., LI J., ZHANG G., JONES K.C. Levels, Distribution and Air-soil Exchange Fluxes of Polychlorinated Biphenyls (PCBs) in the Environment of Punjab Province, Pakistan. Ecotoxicology and Environmental Safety, 97, 189, 2013.

37. RODRÍGUEZ-MURILLO J.C., ZOBRIST J., FILELLA M. Temporal trends in organic carbon content in the main Swiss rivers, 1974-2010. Science of The Total Environment, 502 (1), 206, 2015.

38. IBRAHIM H.Z., ABU-SHANAB M.A. Monitoring of some disinfection by-products in drinking water treatment plants of El-Beheira Governorate, Egypt. Applied Water Science, 3, 733, 2013.

39. JUGDER B.E., BOHL S., LEBHAR H., HEALEY R.D., MANEFIELD M., MARQUIS C.P., LEE M. A bacterial chloroform reductive dehalogenase: purification and biochemical characterization. Microbial Biotechnology, 10, 1640, 2017.

40. EPA. Drinking Water Guidance on Disinfection ByProducts Advice Note No. 4. Version 2. Disinfection ByProducts in Drinking Water. ISBN 978-1-84095-444-9, 2018.

41. WHO. Guidelines for Drinking-water Quality: Fourth edition incorporating the first Addendum. Geneva: World 
Health Organization. 631, 2017. http://www.who.int/water sanitation_health/publications/drinking-water-qualityguidelines-4-including-1st-addendum/en/.

42. LEW S., GLIŃSKA-LEWCZUK K., LEW M. The effects of environmental parameters on the microbial activity in peat-bog lakes. PLoS ONE, 14 (10), 1, 2019.

43. MACCONKEY A.T. Lactose-fermenting bacteria in faeces. Journal of Hygiene, 5, 333-379, 1905.

44. JESUMIRHEWE C., OGUNLOWO P.O., OLLEY M., SPRINGER B., ALLERBERGER F., RUPPITSCH W. Accuracy of conventional identification methods used for Enterobacteriaceae isolates in three Nigerian hospitals. PeerJ, 4, 1, 2016.

45. WIESER A., SCHNEIDER L., JUNG J., SCHUBERT S. MALDI-TOF MS in microbiological diagnosticsidentification of microrganisms and beyond. Applied Microbiology and Biotechnology, 93, 965, 2012.

46. SENG P., ABAT C., ROLAIN J.M., COLSON P., LAGIER J-C., GOURIET F., FOURNIER P.E., DRANCOURT M., LA SCOLA B., RAOULT D. Identification of rare pathogenic bacteria in a clinical microbiology laboratory: impact of MALDI-TOF mass spectrometry. Journal of Clinical Microbiology, 51, 2182, 2013.

47. PANDA A., SRAVYA K., JYOTISH C.S., ALAGIRI S., SHEHLA K. MALDI-TOF mass spectrometry proteomic based identification of clinical bacterial isolates. Indian Journal of Medical Research, 140, 770, 2014.

48. JUNG A., LE CANN P., ROIG B., THOMAS O., BAURÈS E., THOMAS M. Microbial Contamination Detection in Water Resources: Interest of Current Optical Methods, Trends and Needs in the Context of Climate Change. International Journal Environmental Research and Public Health, 11 (4), 4292, 2014.

49. MEDLIN L.K., OROZCO J. Molecular Techniques for the Detection of Organisms in Aquatic Environments, with Emphasis on Harmful Algal Bloom Species. Sensors, 17 (5), 1, 2017.

50. GUO D., LIANG J., CHEN W., WANG J., JI B., LUO S. Bacterial Community Analysis of Two Neighboring Freshwater Lakes Originating from One Lake. Polish Journal of Environmental Studies, 30 (1), 111, 2020.

51. CAI H., JIANG H., KRUMHOLZ L.R., YANG Z. Bacterial Community Composition of Size-Fractioned Aggregates within the Phycosphere of Cyanobacterial Blooms in a Eutrophic Freshwater Lake. PloS One, 9 (8), $1,2014$.

52. DIAS V.C.F., DURAND A-A., CONSTANT P., PRÉVOST M., BÉDARD E. Identification of Factors Affecting Bacterial Abundance and Community Structures in a FullScale Chlorinated Drinking Water Distribution System. Water, 11 (627), 1, 2019.

53. PERRIN Y., BOUCHON D., DELAFONT V., MOULIN L., HECHARD Y. Microbiome of drinking water: A fullscale spatio-temporal study to monitor water quality in the Paris distribution system. Water Research, 149, 375, 2018.

54. FRARACCIO S., STREJCEK M., DOLINOVA I., MACEK T., UHLIK O. Secondary compound hypothesis revisited: Selected plant secondary metabolites promote bacterial degradation of cis-1,2- dichloroethylene (cDCE). Scientific Reports, 7, 1, 2017.

55. NISHINO S.F., SHIN K.A., GOSSETT J.M., SPAIN J.C. Cytochrome P450 Initiates Degradation of cisDichloroethene by Polaromonas sp. Strain JS666. Applied and Environmental Microbiology, 79 (7), 2263, 2013.

56. MOHAPATRA B., SAR P., KAZY S.K., MAITI M.K., SATYANARAYANA T. Taxonomy and physiology of
Pseudoxanthomonas arseniciresistens sp. nov., an arsenate and nitrate-reducing novel gammaproteobacterium from arsenic contaminated groundwater, India. PLOS ONE, 13 (3), 1, 2018.

57. ABURTO-MEDINA A., BALL A.S. Microorganisms involved in anaerobic benzene degradation. Annals of Microbiology, 65, 1201, 2015.

58. NIEPCERON M., MARTIN-LAURENT F., CRAMPON M., PORTET-KOLTALO F., AKPA-VINCESLAS M., LEGRAS M., BRU D., BUREAU F., BODILIS J. GammaProteobacteria as a potential bioindicator of a multiple contamination by polycyclic aromatic hydrocarbons (PAHs) in agricultural soils. Environmental Pollution, 180, 199, 2013.

59. YANUKA-GOLUB K., RESHEF L., RISHPON J., GOPHNA U. Specific Desulfuromonas Strains Can Determine Startup Times of Microbial Fuel Cells. Applied Sciences, 10, 1, 2020.

60. WONGBUNMAK A., KHIAWJAN S., SUPHANTHARIKA M., PONGTHARANGKUL T. BTEX biodegradation by Bacillus amyloliquefaciens subsp. plantarum W1 and its proposed BTEX biodegradation pathways. Scientific Reports, 10, 1, 2020.

61. YOSHIKAWA M., ZHANG M., TOYOTA K. Biodegradation of Volatile Organic Compounds and Their Effects on Biodegradability under Co-Existing Conditions Microbes and Environments, 32 (3), 188, 2017.

62. DAS A., SRINIVASAN M., GHOSH T.S., MANDE S.S. Xenobiotic Metabolism and Gut Microbiomes. PLoS ONE, 11 (10), 1, 2016.

63. GULLNER G., KOMIVES T., KIRÁLY L., SCHRÖDER P. Glutathione S-Transferase Enzymes in Plant-Pathogen Interactions. Frontiers in Plant Science, 9, 1, 2018.

64. ZHANG W., YIN K., LI B., AND CHEN L. A glutathione S-transferase from Proteus mirabilis involved in heavy metal resistance and its potential application in removal of $\mathrm{Hg}^{2+}$. Journal of Hazardous Materials, 261, 646, 2013.

65. DRZEWIECKA D. Significance and Roles of Proteus spp. Bacteria in Natural Environments. Microbial Ecology, 72, 741, 2016.

66. SCHUSTER M., SEXTON D.J., HENSE B.A. Why Quorum Sensing Controls Private Goods. Frontiers in Microbiology, 8, 1, 2017.

67. DING C., ZHAO S., HE J. A Desulfitobacterium sp. strain PR reductively dechlorinates both 1,1,1-trichloroethane and chloroform. Environmental Microbiology, 16 (11), 3387, 2014.

68. HE W.J., SHI M.M., YANG P., HUANG T., YUAN Q.S., YI S.Y., WU A.B., LI HP, GAO C.B., ZHANG J.B., LIAO Y.C. Novel Soil Bacterium Strain Desulfitobacterium sp. PGC-3-9 Detoxifies Trichothecene Mycotoxins in Wheat via De-Epoxidation under Aerobic and Anaerobic Conditions. Toxins (Basel), 12 (6), 1, 2020.

69. OCHSNER A.M, SONNTAG F., BUCHHAUPT M., SCHRADER J., VORHOLT J.A. Methylobacterium extorquens: methylotrophy and biotechnological applications. Applied Microbiology and Biotechnology, 99, 517, 2015.

70. SALAMANCA D., ENGESSER K. Isolation and characterization of two novel strains capable of using cyclohexane as carbon source. Environmental Science \& Pollution Research, 21, 12757, 2014.

71. DOBSLAW D., ENGESSER K.H. Degradation of 2-chlorotoluene by Rhodococcus sp. OCT 10. Applied Microbiology and Biotechnology, 93, 2205, 2012. 
72. MICHENER J.K., VUILLEUMIER S., BRINGEL F., MARXA C.J. Phylogeny Poorly Predicts the Utility of a Challenging Horizontally Transferred Gene in Methylobacterium Strains. Journal of Bacteriology, 196 (11), 2101, 2014.

73. SCHMID-APPERT M., ZOLLER K., TRABER H., VUILLEUMIER S., LEISINGER T. Association of newly discovered IS elements with the dichloromethane utilization genes of methylotrophic bacteria. Microbiology, 143, 2557, 1997.

74. CHAIGNAUD P., MAUCOURT B., WEIMAN M., ALBERTI A., KOLB S., CRUVEILlER S., VUILLEUMIER S., BRINGEL F. Genomic and Transcriptomic Analysis of Growth-Supporting Dehalogenation of Chlorinated Methanes in Methylobacterium. Frontiers in Microbiology, 8, 1, 2017.

75. ROSELlI S., NADALIG T., VUILLEUMIER S., BRINGEL F. The $380 \mathrm{~kb}$ pCMU01 plasmid encodes chloromethane utilization genes and redundant genes for vitamin B12- and tetrahydrofolate-dependent chloromethane metabolism in Methylobacterium extorquens CM4: a proteomic and bioinformatics study. PLoS ONE, 8 (4), 1, 2013.
76. PANDEY V.C., SINGH J.S., SINGH D.P., SING R.P. Methanotrophs: promising bacteria for environmental remediation. International Journal of Environmental Science and Technology, 11, 241, 2014.

77. SINGH J.S., SINGH, D.P. Methanotrophs: An emerging bioremediation tool with unique broad spectrum methane monooxygenase (MMO) enzyme. In Agro-Environmental Sustainability; Springer International Publishing: Berlin/ Heidelberg, Germany, 1, 2017.

78. BADALI N., SHOKROLLAHZADEH S. Biodechlorination of Chlorinated Aliphatic Compounds Trichloroethylene, Dichloromethane, and Dichloroethane in Aqueous Solution, Using Aerobic Sphingopyxix ummariensis Bacteria. Modares Journal of Biotechnology, 9 (1), 39, 2018.

79. BEOLCHINI F., ROCCHETTI L., FONTI V., DELL'ANNO A. Consequences of anaerobic biotreatments of contaminated sediments on metal mobility. International Journal of Environmental Science and Technology, 12, 2143, 2015.

80. TUNG H.H., XIE Y.F. Association between haloacetic acid degradation and heterotrophic bacteria in water distribution systems. Water Research, 43 (4), 971, 2009. 